Finanse, Rynki Finansowe, Ubezpieczenia nr 4/2016 (82), cz. 2

\title{
The Effect of New Socially Responsible Investment Funds in Poland
}

\author{
Pawel Jamróz
}

\begin{abstract}
Aim - The aim of this paper is to analyze, whether the effect of new socially responsible funds occurs in Poland.

Research methodology - The approach of S. Buczek is utilized in this paper to measure the possibility of obtaining abnormal rates of return from investing in six selected Polish investment funds. The study has been carried out from the data of six selected investment funds, which include social responsibility in their investment policy and which were active at the end of 2015. The analysis was based on monthly rates of return for the period from the beginning of the month that followed after the month in which the fund started to operate (or, as in the case of Skok Etycznyl fund, after the month in which the fund has introduced significant changes which included social responsibility to its investment policy) up until the 12th and 36th full month of the funds' operation.

Findings - The results obtained with the average cumulative abnormal returns approach allow to conclude that new socially responsible investment funds were able to obtain rates of return higher than those of the WIG index within the first 12 and 36 full months of operation. Above average returns have been observed for $66.67 \%$ of analyzed funds, but not for all of them. This can indicate a certain anomaly on the investment funds market. Due to a somewhat simplified approach a further study should be carried out to confirm the results. Further analysis should include risk adjusted measures of abnormal returns and an analysis of the evidence for the persistence of long-term performance.

Originality/value - According to the authors knowledge this paper is one of the first ones in Poland to address the effect of new socially responsible investment funds.
\end{abstract}

Keywords: new funds effect, socially responsible investing, investment funds;

\section{Introduction}

In recent years the concept of socially responsible investing has become more and more popular among investors and managers. Socially responsible investing (SRI) is a part of a broader idea of corporate social responsibility (CSR). The growing popularity of socially responsible investing can be linked to: (among others) the outbreak of the financial crisis, and the increase of investors requirements as to the way in which their capital should be allocated. Financial markets are a very important part of developed economies and can be perceived as a valuable source of information. Currently the concept of SRI is not as popular in Poland as in western Europe and North America, however some institutions and investors that do utilize SRI in their investment decisions are beginning to appear. One symptom of

\footnotetext{
* dr Paweł Jamróz, Uniwersytet w Białymstoku, Wydział Ekonomii i Zarządzania, e-mail: p.jamroz@uwb.edu.pl.
} 
the growing popularity of that concept in Poland was the creation in 2009 of the RESPECT index of socially responsible companies listed on the Warsaw Stock Exchange. Investors seek profitable investment strategies that can bring them above average returns at an acceptable level of investment risk. In order to meet the expectations of investors, various investment funds with different strategies and varying levels of risk exposure are being created. Previous studies of Polish investment funds allow to conclude that the effectiveness, and thus investment outcomes, of those funds are greatly affected by the conditions on the financial markets. This has been confirmed by previous studies of among others: Kompa and Witkowska (2010), Jamróz (2013), and Karpio and Żebrowska-Suchodolska (2014). The lack of consistency and repeatability of investment results have also been observed in individual funds. It has been observed that some small and new funds tend to look for investment possibilities which would earn abnormal returns by investing in the stocks of small companies. Benz (1981) and Reinganum (1983) were the first to observe the size effect (also called the capitalization effect $\left.{ }^{1}\right)$. This effect is based on the observation that the stocks of small companies, on average, tend to bring higher rates of return than those of bigger companies.

Scientific literature sometimes states that the study of a small company's effect is analogous with the effect of new, just forming investment funds. The association of that effect in the case of small companies and in the case of new investment funds is not fully justified, since new investment funds are not in all cases stock-investing funds, or they do not need to invest exclusively on the small companies market (Dawidowicz, 2013, pp. 27-28). It is also worth remembering about a possible sample selection error called the survivorship bias which is characterized by selecting only those companies (or funds) that have survived (did not go bankrupt) during the studied period or the studied process. The potential result of survivorship bias is an overestimation of the possibility of success and an underestimation of the possibility of failure (incurring losses).

Additionally a fund does not have to be new to have small market capitalization. The topic of the effect of new socially responsible investment funds has not been previously studied in Polish scientific literature. That is why it has become the subject matter of this paper. Although the investment outcomes of funds is a broadly studied topic in global scientific literature, there are not that many research papers published on the subject of newly formed investment funds. One such study was published in an article by Timmerman and Blake (1998, pp. 57-77). While studying the British investment funds market, the authors observed (among other findings) that investment funds obtained above average returns during the first year of their operation. Another example is the study by Karoui (2008) who observed similar results for American investment funds.

\footnotetext{
${ }^{1}$ Market capitalization is calculated as the product of the number of shares of a company and the current market price of the share.
} 


\section{Size of the company effect}

The effect discovered by Banz and Reinganum contradicts the efficient market hypothesis that is closely related to the classic CAPM model. The results of studies conducted in the last decade of the previous century indicate however, that the capitalization effect is not a universal rule occurring at every point in time and on every market. Later research by Reinganum (1990, pp. 127-148) showed that the effect is much weaker for the NASDAQ-listed companies than for the companies listed on the NYSE ore AMEX markets. Additionally the effect occurs with varying intensity depending on the time period and is characterized by high rates of return from investment portfolios containing stocks of companies with smallest market capitalizations.

Scientific literature suggests many possible explanations for the capitalization effect. Early explanations were concentrated on the possible misestimating of the CAPM model parameters. According to Roll (1981, pp. 879-888), stocks of small capitalization companies tend to trade in low volumes and thus exhibit high levels of autocorrelation in the returns time series. Because of that, estimating risk with the use of daily returns can lead to estimation errors and the misestimating of the CAPM model. This essentially suggests that in order to estimate CAPM parameters correctly one should include the market capitalization of the company as one of the variables in the CAPM model. Berk (1997, pp. 12-18) concluded that the capitalization effect does not occur if the size of the company is measured correctly. Berk states that the market capitalization of a company's equity should be measured as the expected value of future cash flows from a company's stocks discounted at the present time.

A broad description of the possible theoretical causes for the anomaly has been given in Polish scientific literature by P. Skwarek (2001, pp. 356-366). On the other hand proponents of behavioral finance believe that higher returns on small companies stocks are a result of ill-informed investors who undertake their investment decisions based on speculations instead of an in-depth analysis of available information. Shleifer and Vishny (1997, pp. 35-55) conclude that deviations from fundamental values can not always be quickly canceled out by the actions of well-informed arbitrageurs. The irrational decisions of small investors can happen for many reasons such as: limited investment horizons, sudden requirement for financial liquidity, and also psychological aspects.

In his study Skwarek analyzed stock market prices of 125 companies over a 74-month period of 1.11.1994-29.12.2000. His results indicate, that in the case of the Polish capital market, a statistically significant effect occurs for the stocks of medium capitalization companies. This means that there existed a possibility for obtaining above average returns by investing in the stocks of companies with market capitalization from PLN 613,24 m. to PLN 1178,75 m. On the other hand, results obtained for small capitalization companies suggested a rather opposite effect. In the study by Czekaj, Woś and Żarnowski (2004), authors' analyzed the prices of between 44 and 119 stocks listed on the main stock market from the fourth quarter of 1995 up to and including the third quarter of 2000. The researchers 
analyzed decile and quintile portfolios, and have observed a monotonic relationship between the portfolio's rate of return and the average market capitalization of the companies in the portfolio. In the case of decile portfolios the highest annual rates of return $(+26.5 \%)$ have been achieved for the portfolios containing stocks of high market capitalization companies and the smallest capitalization portfolio achieved a return of $+8.6 \%$. The same property has also been observed in the case of quintile portfolios. Big companies allowed for an investment premium of +26.2 percentage points - expressed as the difference between the rates of return from the most and least profitable portfolios. However, statistical tests did not confirm the statistical significance of those results.

The study by Buczek (2005) included 65 stock market listed companies with continuous price listings from 2001 until 2004. It did not confirm the results obtained by Czekaj, Woś and Żarnowski (2001). Investing in small capitalization companies allowed to obtain above average returns and the stocks of companies with big market capitalizations obtained lower returns. The author states that this is consistent with the trends observed on most world capital markets, where high rates of return from the stocks of big companies were apparent in the 1990's. At the beginning of the 21st century the Polish stock market returned to the earlier observed tendency above average returns from the stocks of small capitalization companies. Such tendencies in the 21 century were observed in a study by Czekaj (2014, pp. 110-111, 133), the results indicated that a company's market capitalization had an impact on the returns of the reference stock portfolio - the stocks of smaller companies achieved higher investment premiums.

\section{Research methodology}

According to the authors knowledge this paper is one of the first ones in Poland to study the effect of new socially responsible investment funds. This study utilizes the approach of S. Buczek (2005), which is based on comparing the results of new investment funds. Buczek observed an anomaly in this segment of the market. The first hypothesis of this paper has been formulated in the following way: New investment funds that adopt the CSR concept, were able to obtain better investment outcomes compared to the benchmark specified as the WIG index of the Warsaw Stock Exchange. The second hypothesis is as follows: New funds were able to obtain results better than the benchmark in the first three years of their operation. The study has been carried out from the data of six selected investment funds (see Table 1) that include social responsibility (SRI) in their asset selection policy as opposed to focusing exclusively on the financial outcomes of those assets. Additionally only funds which were active at the end of 2015 were taken into consideration. 


\section{Table 1}

Studied investment funds that subscribe to the SRI concept

\begin{tabular}{llll}
\hline Shortened name & Full name of the fund & $\begin{array}{l}\text { Managing investment } \\
\text { fund company }\end{array}$ & Start of operation \\
\hline INVINF & $\begin{array}{l}\text { INVESTOR Sektora Infrastruktu- } \\
\text { ry i Informatyki }\end{array}$ & INVESTORS TFI & $28.01 .2008 \mathrm{r}$. \\
INVAG & INVESTOR AGROBIZNES & INVESTORS TFI & $7.10 .2008 \mathrm{r}$. \\
PKOTIG & $\begin{array}{l}\text { PKO TECHNOLOGI I INNOWACJI } \\
\text { GLOBALNYCH }\end{array}$ & PKO TFI & $7.04 .2010 \mathrm{r}$. \\
PZUEME & PZU FIO ENERGIA MEDYCYNA & TFI PZU & $29.07 .2010 \mathrm{r}$. \\
SKE2 & EKOLOGIA & & $18.08 .2010 \mathrm{r}$. \\
SKE1 & SKOK SFIO ETYCZNY 2 & TFI ALTUS & $28.07 .2011 \mathrm{r}$ * date of the chan- \\
\hline
\end{tabular}

Source: own elaboration based on data from: http://analizy.pl.

The analysis was based on historical monthly logarithmic rates of return ${ }^{2}$, for the period from the beginning of the month that followed after the month in which the fund started to operate (or, as in the case of the Skok Etyczny 1 fund, after the month in which the fund introduced significant changes which included social responsibility to its investment policy) up until the 12th and 36th full month after that period. Future research should exclude the Investor Agrobiznes fund because of the changes in its investment policy and renaming of the fund to the Investor Niemcy on the 24.02.2016. Abnormal monthly rates of return were calculated in the following way (Buczek, 2005, p. 178):

$$
u_{j, t}=\frac{1+r_{j, t}}{1+r_{W I G, t}}-1
$$

where: $r_{j, t}$ - the monthly logarithmic rate of return of th ej-th fund at time $t, r_{W I G, t}-$ the monthly logarithmic rate of return from the stock market index at time $t$. The average abnormal rate of return of the whole sample $\left(u_{a a, t}\right)$ has been obtained by dividing the sum of abnormal rates of return for the studied funds by the number of observations according to the formula (Buczek, 2005):

$$
u_{a a, t}=\frac{\sum_{j=1}^{n} u_{j, t}}{\mathrm{n}}
$$

\footnotetext{
${ }^{2}$ Logarithmic rates exhibit better statistical properties than standard arithmetic ones, such as additivity.
} 
Finally the cumulative average annual abnormal rates of return for two studied time periods have been calculated as follows (Buczek, 2005):

$$
\begin{aligned}
& u_{\text {cum } 12}=\prod_{t=1}^{12}\left(1+u_{a a, t}\right)-1 \\
& u_{c u m 36}=\prod_{t=1}^{36}\left(1+u_{a a, t}\right)-1
\end{aligned}
$$

The presented approach of S. Buczek is not without its disadvantages, those include, among others: no inclusion of the prevailing market conditions in the analysis (Dawidowicz, 2013, p. 30), and the use of standard (arithmetic) rates of return. Because of that, logarithmic rates have been used for this study and an additional period of 36 six months has been added - since the minimum recommended period for investing in investment funds is usually at least 3 years. On the other hand, one undoubtable advantage of this approach is the ease of calculation and no requirement for the return data to be normally distributed. This is important since the normality requirement is usually not fulfilled for the returns from Polish and European capital markets (Koronkiewicz, Jamróz, 2014, pp. 103-113). Returns for this study have been calculated from the monthly closing prices of the analyzed funds and the WIG index. The price data was obtained from two websites: http://stooq.pl and http://analizy.pl.

\section{Empirical results}

Basic descriptive statistics of the analyzed funds and the WIG index (in both the 12-month and 36-month time periods) are presented below in Table 2. Studied funds exhibited high levels of variability, which is confirmed by the variation coefficients of more than $100 \%$ for both time periods. The lowest variability was observed in the case of "Investor Sektora Infrastruktury i Informatyki” for the 12-month period. The highest variability was exhibited by the Skok Etyczny 2 fund for the 36-month period. Kurtosis levels different than 3 indicate that none of the funds exhibited normally distributed returns. Most of the funds achieved a positive average rate of return with positive skewness for the studied time-periods. Both the highest and the lowest single monthly rates of return were obtained by the Investor Sektora Infrastruktury i Informatyki fund. Risk measured by the standard deviation of monthly return rates was the highest for the INVINF fund and lowest for the SKOK Etyczny 1 fund.

Cumulative average abnormal rate of return for the 12 month time period after the inception of new funds was equal to $9.10 \%$ (see Figure 1). The results of this study indicate that the average returns of the selected new socially responsible investments funds were better than those of the WIG index benchmark for every month of the first 12 full months of operating. Before formulating final conclusions, it is worthwhile to analyze how the cumulative abnormal return rate evolves with each period for each fund (see Table 3). 
Table 2

Basic descriptive statistics of the studied funds

\begin{tabular}{|c|c|c|c|c|c|c|}
\hline & INVINF & INVAG & PKOTIG & PZUEM & SKE2 & SKE1 \\
\hline \multicolumn{7}{|c|}{ 12-month period } \\
\hline Min & -0.2544 & -0.0164 & -0.024 & -0.0099 & -0.0760 & -0.0215 \\
\hline Max & 0.0557 & 0.1055 & 0.0493 & 0.0951 & 0.0458 & 0.0112 \\
\hline Mean & -0.0642 & 0.0283 & 0.0113 & 0.0184 & -0.0094 & 0.0019 \\
\hline Median & -0.0480 & 0.0272 & 0.0128 & 0.0117 & -0.0053 & 0.0043 \\
\hline Std. deviation. & 0.0747 & 0.0366 & 0.0220 & 0.0282 & 0.0318 & 0.0089 \\
\hline Variation coef. & $116.31 \%$ & $129.34 \%$ & $194.14 \%$ & $153.19 \%$ & $338.99 \%$ & $454.94 \%$ \\
\hline Skewness & -1.2833 & 0.6721 & 0.0252 & 1.9514 & -0.4619 & -1.806 \\
\hline Curtosis & 3.7452 & 0.0265 & -0.6640 & 5.0071 & 0.7679 & 4.0175 \\
\hline \multicolumn{7}{|c|}{ 36-month period } \\
\hline Min & -0.2544 & -0.0911 & -0.0597 & -0.0171 & -0.0760 & -0.0215 \\
\hline Max & 0.1723 & 0.1107 & 0.0712 & 0.0951 & 0.0900 & 0.0197 \\
\hline Mean & -0.0112 & 0.0149 & 0.0046 & 0.0142 & -0.0008 & 0.0028 \\
\hline Median & -0.0098 & 0.0139 & 0.0065 & 0.0106 & -0.0045 & 0.0034 \\
\hline Std. deviation. & 0.0708 & 0.0384 & 0.0286 & 0.0238 & 0.0398 & 0.0067 \\
\hline Variation coef. & $629.85 \%$ & $256.65 \%$ & $622.01 \%$ & $167.50 \%$ & $5191.16 \%$ & $242.37 \%$ \\
\hline Skewness & -0.5805 & 0.1504 & 0.1101 & 1.2197 & 0.2156 & -1.1167 \\
\hline Curtosis & 3.7166 & 1.5701 & 0.3923 & 2.4961 & -0.3190 & 4.6064 \\
\hline
\end{tabular}

Source: own elaboration.

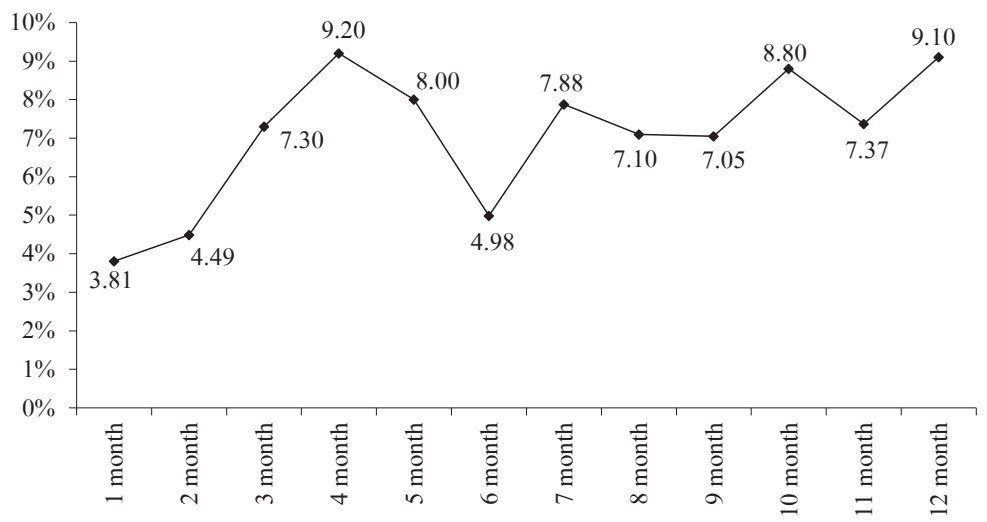

Figure 1. Cumulative abnormal returns of the studied funds for the 12-month period after starting operating

Source: own elaboration.

The analysis of the cumulative abnormal returns for the 12-month period yields a conclusion that 4 out of 6 funds achieved positive abnormal returns. The two funds that did not achieve positive abnormal returns were: INVINF and SKOK Etyczny 2, in the case of the latter fund it was the weak outcomes in the first four months of operating that resulted in 


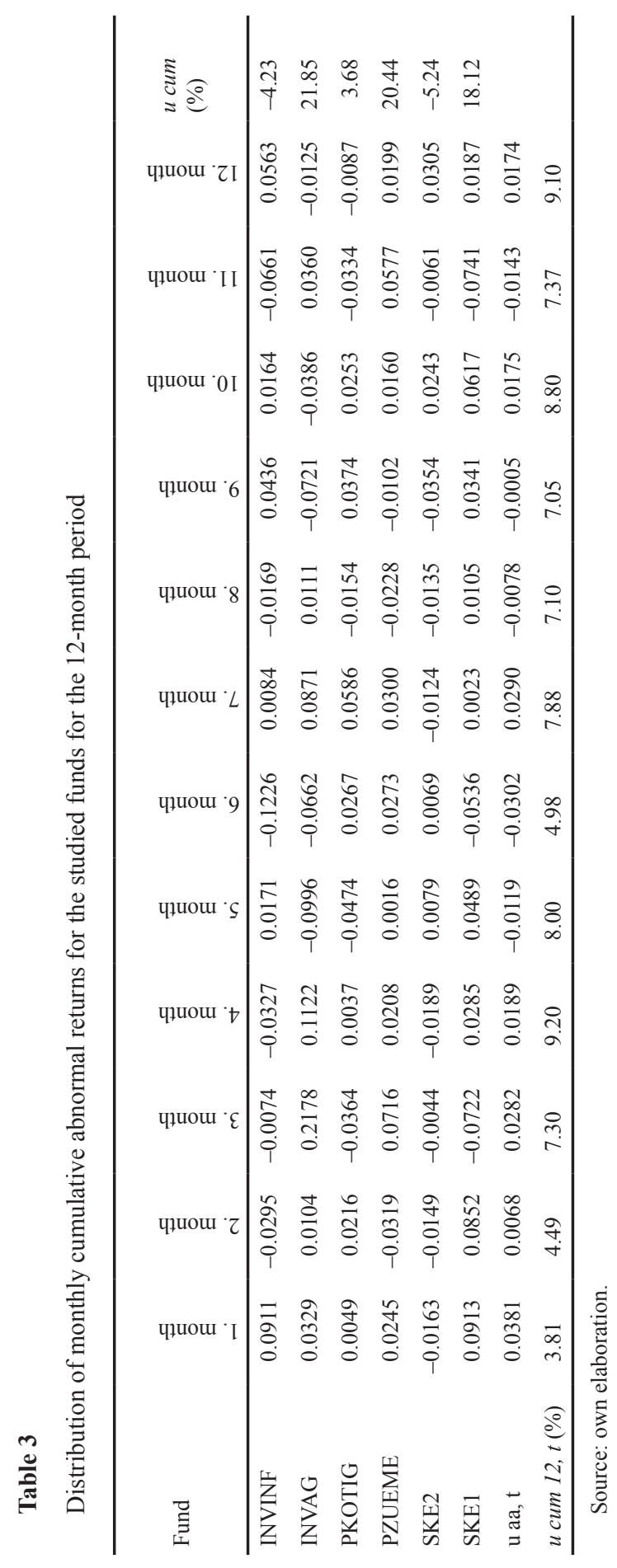


overall negative cumulative abnormal returns. It is worth noting that three funds managed to achieve very good results within the first 12 months: Investor Agrobiznes, PZU Energia Medycyna Ekologia and SKOK Etyczny 1. Some of the funds began operating during good market conditions and some during bad market conditions caused by the financial crisis. Above-average performance can be the result of the fact that it is easier to manage a small fund and it can also be a result of the so called marketing game, which attracts wealth managers. In order to attract potential investors to new and unknown funds, investment fund companies undertake many marketing activities (such as: press conferences, or meetings with potential clients. Those activities are however associated with certain costs and they do not guarantee a success in the form of cash inflows to the fund.

Nevertheless the cumulative abnormal monthly rate of return of the analyzed funds, which began operating between the years 2008 and 2011, was positive in relation to the WIG index. Because the same methodology was utilized, one can compare the results of this study with the studies of new investment funds by S. Buczek (2005) or Dawidowicz (2013). Those studies indicated that new investment funds also performed better than the benchmarks.

An analysis of the cumulative mean abnormal returns for the 36-month time period indicates that three out of six funds (see Table 4.) were able to obtain positive above average returns. It is worth noting that the best results were obtained by the PZU Energia Medycyna Ekologia fund, which is linked to an insurance company with big assets, and most likely access to big amounts of information. The study shows that the average result of all of the analyzed new socially responsible investment fund was better than the benchmark in each of the 36 months of operating (see Figure 2).

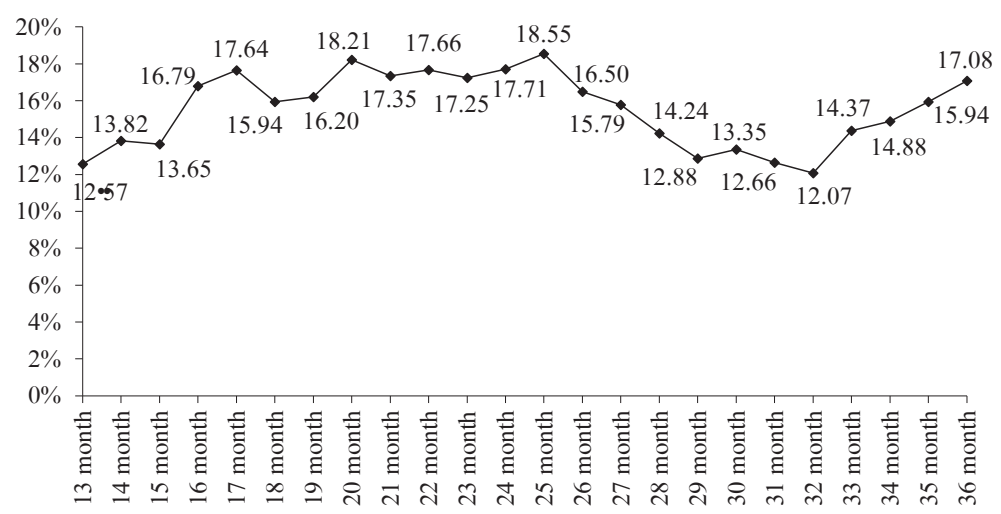

Figure 2. Cumulative abnormal returns of the studied funds for the 36-month period after the starting operating

Source: own elaboration. 


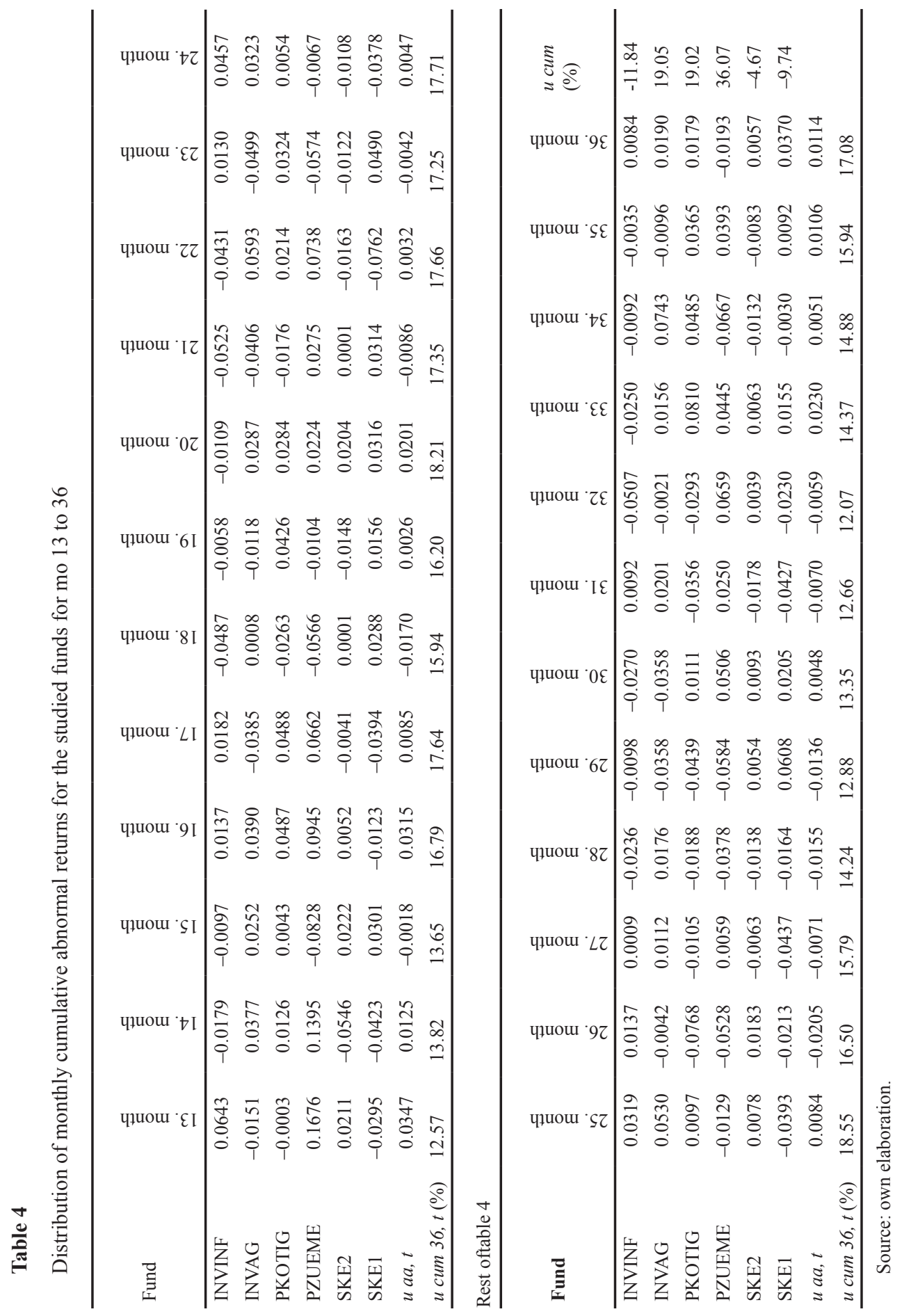


Additionally not all of the analyzed funds managed to achieve a positive cumulative return, three out of six funds obtained negative abnormal returns. Hence the results of this study do not fully suggest that every new socially responsible fund is predestined to obtain returns higher than those of the broad market index WIG in the first three years of operating. The presented analysis requires further in-depth observations, since for example: the relative ease of managing a smaller fund could have had an influence on the positive results obtained.

\section{Conclusions}

The study presented did not confirm the popular opinion that investment funds usually underperform with respect to common stock market benchmarks. The results obtained, with the use of cumulative abnormal returns methodology, allow to state that new socially responsible investment funds were able to achieve higher rates of return then those of the WIG index, within the first 12 and 36 months of operating. This supports the two formulated hypotheses. Above average results have been observed for $66.67 \%$ of the analyzed funds, but not for all new funds. Hence, at this stage of the research, an investment strategy that would consist of investing in new socially responsible funds can be considered a risky one. This can indicate a certain anomaly on the investment funds market. Due to a somewhat simplified approach a further study should be carried out to confirm the results. A Further analysis should include risk adjusted measures of investment performance and an analysis of evidence for the persistence of long-term performance.

\section{References}

Banz R.W. (1981). The relationship between return and market value of common stocks. Journal of Financial Economics, 9 .

Berk J.B. (1997). Does Size Really Matter? Financial Analysts Journal, 53.

Blake D., Timmerman A. (1998). Mutual fund performance: Evidence from the UK. European Finance Review, $2(1)$.

Buczek S. (2005). Efektywność informacyjna rynków akcji. Teoria a rzeczywistość, Warszawa: Warsaw School of Economics Publishing House.

Czekaj J. (red.) (2014). Efektywność giełdowego rynku akcji w Polsce z perspektywy dwudziestolecia. Warszawa: PWE.

Dawidowicz D. (2013). Efekt nowych funduszy inwestycyjnych akcji polskich w latach 2005-2012. Folia Pomeranae Universitatis Technologiae Stetinensis seria Oeconomica, 301 (71), 27-34.

Jamróz P. (2013). Efektywność wybranych FIO rynku akcji w latach 2003-2011. Zeszyty Naukowe Uniwersytetu Szczecińskiego - Finanse, Rynki Finansowe, Ubezpieczenia, 63 (768), 193-206.

Jamróz P. (2014). Badanie efektywności zarządzających funduszami społecznie odpowiedzialnymi. Zeszyty Naukowe Uniwersytetu Szczecińskiego, 811, Studia i Prace Wydziału Nauk Ekonomicznych i Zarzadzania, 36 (2), 273-285.

Karoui A. (2008). Performance Analysis of New Mutual Funds: a Bayesian Approach,working paper, http://papers. ssrn.com/sol3/papers.cfm?abstract_id=1102797 (30.01.2016). 
Karpio A., Żebrowska-Suchodolska D. (2014). Ocena zarządzania portfelami otwartych funduszy inwestycyjnych z wykorzystaniem różnych miar efektywności inwestycyjnej. Studia Ekonomiczne. Zeszyty Naukowe Uniwersytetu Ekonomicznego w Katowicach, 207 (14), 136-147.

Kompa K., Witkowska D. (2010). Porównanie efektywności wybranych otwartych funduszy inwestycyjnych w okresie hossy i bessy. Acta Scientiarum Polonorum Oeconomia, 9 (3), 169-180.

Koronkiewicz G., Jamróz P. (2014). Comparison of the Tails of Market Return Distributions. Optimum. Studia Ekonomiczne, 5 (71), 103-113.

Reinganum M.R. (1983). Misspecification of capital asset pricing: Empirical anomalies based on earnings yields and market values. Journal of Financial Economics, 12, 89-104.

Reinganum M.R. (1990). Market Microstructure and Asset Pricing: An Empirical Investigation of NYSE and NASDQ securities. Journal of Financial Economics, 28, 127-148.

Roll R. (1981). A Possible Explanation of the Small Firm Effect. Journal of Finance, 36, 879-888.

Shleifer A., Vishny R.W. (1997). The Limits of Arbitrage. Journal of Finance, 52, 35-55.

Skwarek P. (2001). Efekt wielkości spółki na polskim rynku kapitałowym. In: W. Frąckowiak (red.), Z badań nad rynkiem kapitałowym w Polsce. Poznań: Poznań University of Economics and Business Printing House.

\section{EFEKT NOWYCH FUNDUSZY INWESTYCYJNYCH SPOŁECZNIE ODPOWIEDZIALNYCH W POLSCE}

Streszczenie: $\mathrm{Cel}$ - Celem artykułu jest analiza występowania efektu nowych funduszy inwestycyjnych społecznie odpowiedzialnych w Polsce.

Metodologia badania - W artykule zastosowano podejście S. Buczka (2005) w przypadku możliwości osiągania ponadprzeciętnych stóp zwrotu z nowych funduszy inwestycyjnych w Polsce. Badanie przeprowadzone zostało na wybranych sześciu funduszach inwestycyjnych, które w swojej polityce inwestycyjnej kierowały się zasadami społecznej odpowiedzialności biznesu i funkcjonowały na koniec 2015 roku. Badaniu poddano historyczne miesięczne logarytmiczne stopy zwrotu w okresie od miesiąca następującego po miesiącu, w którym uruchomiono fundusz (lub zmieniono istotnie politykę inwestycyjną jak miało to miejsce w przypadku funduszu Skok Etyczny 1), do 12 oraz 36 miesięcy ich funkcjonowania na rynku.

Wynik - Zaprezentowane wyniki pozwalają na stwierdzenie, iż przy zastosowaniu metodyki skumulowanej anormalnej średniej stopy zwrotu nowe fundusze inwestujące społecznie odpowiedzialnie w pierwszych pełnych 12 oraz 36 miesiącach działalności osiągały stopy zwrotu wyższe niż stopa zwrotu z indeksu WIG. Ponadprzeciętne wyniki uzyskano w przypadku $66.67 \%$ badanych funduszy, lecz nie dla wszystkich nowych funduszy. Może to świadczyć o pewnej anomalii na rynku funduszy inwestycyjnych, jednak ze względu na uproszczoną metodykę badania niezbędne jest jego pogłębienie o metody oceny efektywności funduszy inwestycyjnych skorygowanych o ryzyko, jak również trwałości uzyskiwanych wyników.

Oryginalność/wartość - Artykuł zgodnie z wiedzą autora jest jednym z pierwszych w Polsce opracowań, w którym badano występowanie efektu nowych funduszy społecznie odpowiedzialnych.

Słowa kluczowe: efekt nowych funduszy; inwestycje społecznie odpowiedzialne; fundusze inwestycyjne.

\section{Citation}

Jamróz P. (2016). The Effect of New Socially Responsible Investment Funds in Poland. Finanse, Rynki Finansowe, Ubezpieczenia, 4 (82/2), 495-506. DOI: 10.18276/frfu.2016.4.82/2-43. 